\title{
EESTRSE Notes for Authors
}

Earth and Environmental Science Transactions of the Royal Society of Edinburgh publishes peer-reviewed, original scientific research papers, reviews and short communications on fields across the broad spectrum of the Earth and its surface environments. Articles do not need to have a specifically Scottish focus, nor are authors required to be Fellows of the Society. Articles should have relevance to a worldwide audience, even if the study is focused on a single geographic site. Papers should make topical, substantial and scholarly contributions, and the Editors are keen to encourage interdisciplinary papers. Discussions of articles previously published in the Transactions and reviews of topics of current interest are also invited. There are no page charges; however, if fold-outs or colour illustrations are envisaged, the Journals Officer should be consulted prior to submission (publications@royalsoced.org.uk). All new submissions are sent to at least two reviewers.

\section{Submission}

Manuscripts should be submitted electronically, with separate Text, Table and Figure files - Text in WORD format; Tables in Excel; Figures as low-res PDFs, preferably at publication size. Any queries regarding submission may be sent to the RSE Journals Officer, as above - publications@royalsoced. org.uk - but as from 12 May 2016, all new submissions should be uploaded to the EESTRSE ScholarOne site through the following link: https://mc.manuscriptcentral.com/tre Submissions to Earth and Environmental Science Transactions of the Royal Society of Edinburgh must not have been published, or be under consideration, elsewhere.

\section{Preparation of papers}

\subsection{Language}

We recommend that non-English-speaking authors have their manuscripts checked by an English language native speaker before submission, to ensure that submissions are judged exclusively on academic merit. A number of third-party services specialising in language editing and/or translation can be found here: http://journals.cambridge.org/action/stream?pageId=8728\& level $=2 \&$ menu $=$ Authors \&pageId $=3608$. Please note: the use of any of these services is voluntary, and at the authors' own expense.

\subsection{Title page}

The first page should show: (a) a title that is concise and informative; (b) the name(s) and full address(es) of the author(s); and (c) a running head abbreviation of the title of no more than 50-60 characters. Papers by more than one author should be submitted with statements from all the authors, approving the paper in its entirety and its submission to EESTRSE, and naming the author responsible for correspondence.

\subsection{Abstract and Key Words}

The second page should contain an Abstract of around 300 words, intelligible without reference to the text or references, and a list of Key Words (NB: words not already in the title) of no more than 150 characters, in alphabetical order.

\subsection{Text}

Text should start on the third page. Words to be printed in italics, e.g. names of taxa, should be underlined, unless already in italic typeface. Use capital letters for formal terms only. The metric system should be used throughout. Abbreviate compass points to N, NW, NW, SE etc. Enclose map references in square brackets, e.g. [NM 4437 0293]. In papers on systematic palaeontology, anatomical abbreviations should be included in the relevant Figure captions, rather than listed in a separate section. See a recent issue for general systematics style.

\subsection{Headings}

The introductory section should have no heading. The first headed section after the introduction should be numbered as $\mathbf{1}$. Primary headings are numbered consecutively $\mathbf{1}, \mathbf{2}, \mathbf{3}$, etc. Secondary headings are 1.1., 1.2., 1.3., etc. Both should appear flush left, with their text starting on a separate line below. Tertiary headings (1.1.1., 1.1.2., etc.) should start a new paragraph, with indent, and should be followed by a full stop and the text to which they refer. All headings should be in bold. Cross-references in text should be to a section (e.g., (see section 2.3)), not to a page.

\subsection{Footnotes}

Do not use footnotes in main text.

\subsection{References}

All publications cited in the text, including those pertaining to the authorship of taxa, must be included in the Reference list, which is arranged in alphabetical order by author.

2.7.1. Citation of Figures and References in text. References to Figures are "Figure 1a" in a sentence, but "(Fig. la)", "(Figs 1, 3a, 5)" in parentheses. References to other authors' figs, etc. take lower case initial to differentiate from references to Figures in current paper: "(Smith 1990, fig. 4; Adams 1993, pl. 2, fig. 3; Fig. 3)"

When referring to Refs in text: "Smith \& Jones (1990)" - for author plus one other; "Smith et al. (1992)" - when more than two authors. When listing Refs in parentheses: date order, and alphabetical within that; allow ampersands: "(Smith 1990, 1997, 2000; Adams et al. 1993; James \& Drury 1993; Smith et al. 2000; Smith \& Jones 2001; James et al. 2004)"

2.7.2. References at end. Only published or in press items, or unpublished theses with the University clearly specified, are to be included in the References. Journal and series titles should be written out in full, upper and lower case italics; no comma after; volume numbers in bold; one space between author initials (i.e., Clarkson, E. N. K., not Clarkson, E.N.K.); ampersand (\&), not 'and' for final author in multi-authored papers (i.e., Smith, Brown \& Clark, not Smith, Brown and Clark).

References at the end should be ordered thus:

(i) single author - alphabetically by initials, and then by date; e.g., Smith, A. B. 1990; Smith, A. B. 1996; Smith, C. D. 1989; Smith, C. D. 1990. (ii) author plus two or more co-authors (et al. in text) - by date; e.g., Smith, Jones \& Clerk 1993; Smith, Brown \& Clerk 1995a (= Smith et al. 1995a in text); Smith, Jones \& Clerk 1995b ( Smith et al. 1995b in text); Smith, Clerk, Brown \& Jones 1997.

(iii) author plus one other - alphabetical by 2 nd author, and then by date within that; e.g., Smith \& Brown 1997; Smith \& Jones 1987; Smith \& Jones 1996.

Set out as in examples below:

Copper, P. \& Gourvennec, R. 1996. Evolution of the spire-bearing brachiopods, (Ordovician-Jurassic). In Copper, P. \& Jin, J. (eds) Brachiopods, 81-88. Rotterdam: A. A. Balkema.

Chappell, B. W. \& White, A. J. R. 1992. 1- and S-type granites in the Lachlan Fold Belt. Transactions of the Royal Society of Edinburgh: Earth Sciences 83, 1-26.

Jarvik, E. 1980. Basic structure and evolution of vertebrates, Vol. 1, 74 98. London: Academic Press.

\section{Preparation of Tables and Figures}

\subsection{Tables}

Tables should be numbered, and cited, consecutively throughout the paper, and provided on separate pages at the end of the MS, not embedded in the text. Each Table should have a caption. For layout of analytical data, see tables published in previous issues. Authors should send published analyses of igneous rocks to the UK IGBA file.

\subsection{Figures}

Illustrations should be numbered, and cited, consecutively throughout the paper. A list of figure captions should be provided on a separate page after the References; figures and figure captions should not be embedded in the text. A scale should be shown on the figure (e.g., a bar scale on a photomicrograph), rather than giving magnifications in the caption, in case figures are reduced or enlarged. Large figures can be subdivided for reproduction on facing pages. Fossil illustrations should be illuminated top left. Figures in PDF format are sufficient for submission purposes. Should a paper be accepted for publication, high-quality electronic files will be requested. Detailed guidelines for their production are available on request from the RSE's Journals Officer (publications@royalsoced.org.uk)

\section{Proofs and offprints}

A typeset PDF proof of an accepted paper will be sent to the corresponding author for checking. 25 offprints (with covers) of a published paper are provided gratis and additional offprints may be ordered (in batches of 25) when checked proofs are returned. A PDF of the final published paper (the 'Publisher's Version') can be supplied on request to the Journals Officer.

\section{Copyright/Open Access}

The RSE now operates a 'hybrid' Open Access model for its journals, for accepted papers submitted on or after 1 April 2013. On acceptance, authors will be given the option of having their papers published either under a regular publication agreement or under a fully Open Access agreement. Under the regular publication ('Green') option, authors will be asked to sign the Journal's standard transfer of copyright form. If authors choose the full (Gold') Open Access option, they will be asked to sign the alternative Open Access form and, upon payment of a one-off Article Processing Charge (APC) of GBP 1,780/USD 2,835 (for papers accepted from August 2015 onwards), the final published Version of Record will be made freely available to all in perpetuity, and will be published under a creative commons licence, enabling its free re-use and re-distribution. Please note that publication under a fully Open Access agreement is part of the Cambridge Open Option. For more details, please see: http://journals. cambridge.org/action/displaySpecialPage?page $\mathrm{Id}=4576$.

Authors are also asked to ensure that any electronic versions of their papers clearly state EESTRSE as the official original place of publication. 


\section{Earth and Environmental Science Transactions of the Royal Society of Edinburgh}

\section{Volume 1072018 (for 2016) Part 4}

Richard A. BATCHELOR

Do Neoproterozoic (Moine) calc-silicate rocks represent metamorphosed tuffs? A geochemical

reappraisal

Francis M. ELLIOTT

An early actinopterygian ichthyofauna from the Scottish Lower Coal Measures Formation:

Westphalian A (Bashkirian)

351-394

\section{Transactions available on-line:}

The journal Earth and Environmental Science Transactions of the Royal Society of Edinburgh is available on subscription as both print plus online and online only. (Online ISSN: 1755-6929). See inside front cover for ordering details.

As from 2007 (volume 98), this journal is hosted by the Cambridge Journals Online (CJO) service (now Cambridge Core), which can be found at https://www.cambridge.org/core/journals/earth-and-environmental-sciencetransactions-of-royal-society-of-edinburgh

This page on the Cambridge Core site also, under 'All issues', the complete digitised archive of the journal under its former titles of Transactions of the Royal Society of Edinburgh: Earth Sciences (volumes 71-97 (1980-2006)) and Transactions of the Royal Society of Edinburgh (volumes 1-70 (1785-1979)).

Feedback: All comments are welcome - either regarding the quality and usability of the electronic product or the process of registration on-line. Please send comments to: publicationsatherse.org.uk

(Issue date 31 March 2018)

ISSN 1755-6910 TREASO 107, 333-394 (2018, for 2016)

Published on behalf of the RSE by the RSE Scotland Foundation, 22-26 George Street, Edinburgh EH2 2PQ

Typeset and Printed* in the UK by Henry Ling Limited, at the Dorset Press, Dorchester, DT1 1HD

Distributed and Marketed by Cambridge University Press, Cambridge, UK

The RSE Scotland Foundation, a charitable body connected to The Royal Society of Edinburgh, is Scottish Charity No. SC024636

*This journal issue has been printed on FSC ${ }^{T M}$-certified paper and cover board. FSC is an independent, nongovernmental, not-for-profit organization established to promote the responsible management of the world's forests. Please see www.fsc.org for information.

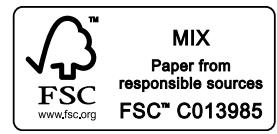




\title{
EARTH AND ENVIRONMENTAL SCIENCE TRANSACTIONS
}

\author{
$\mathrm{OF}$ \\ THE ROYAL SOCIETY \\ $\mathrm{OF}$ \\ EDINBURGH
}

Volume 107

PUBLISHED BY THE RSE SCOTLAND FOUNDATION

22-26 GEORGE STREET, EDINBURGH EH2 2PQ 


\section{CONTENTS OF VOLUME 107}

Hongyu YI, Jonathan P. TENNANT, Mark T. YOUNG, Thomas J. CHALLANDS, Davide FOFFA, John D. HUDSON, Dugald A. ROSS and Stephen L. BRUSATTE

An unusual small-bodied crocodyliform from the Middle Jurassic of Scotland, UK, and potential evidence For an early diversification of advanced neosuchians

Yoshitaka KAKUWA and James D. FLOYD

Trace fossils in Ordovician radiolarian chert successions in the Southern Uplands, Scotland

John PARNELL, Mas'ud BABA and Stephen BOWDEN

Emplacement and biodegradation of oil in fractured basement: the 'coal' deposit in Moinian gneiss at Castle Leod, Ross-shire

L. M. E. McCOBB and L. E. POPOV

Late Ordovician trilobites from the Mayatas Formation, Atansor area, north-central Kazakhstan

Brian R. BELL and Ian T. WILLIAMSON

Fossil trees, tree moulds and tree casts in the Palaeocene Mull Lava Field, NW Scotland: context, formation and implications for lava emplacement

\section{FOSSIL INSECTS, ARTHROPODS AND AMBER - SPECIAL ISSUE}

Andrew J. ROSS

Fossil Insects, Arthropods and Amber: Preface

Pierre GUERIAU, Nicolas RABET and Eva DU TIEN HAT

The Strud crustacean fauna (Late Devonian, Belgium): updated review and palaeoecology of an early continental ecosystem

Neil D. L. CLARK, Randall F. MILLER and Andrew J. ROSS

The distribution of Schramocaris (Eumalacostraca, Crustacea) along the northwestern coast of the Rheic Ocean during the Lower Carboniferous

Jakub PROKOP, Martina PECHAROVÁ, Edmund A. JARZEMBOWSKI and Andrew J. ROSS

New palaeodictyopterans from the Late Carboniferous of the UK (Insecta: Palaeodictyopterida)

Jacek SZWEDO

The unity, diversity and conformity of bugs (Hemiptera) through time

Richard S. KELLY, Andrew J. ROSS and Edmund A. JARZEMBOWSKI

Earwigs (Dermaptera) from the Mesozoic of England and Australia, described from isolated tegmina, including the first species to be named from the Triassic

Agnieszka SOSZYŃSKA-MAJ, Wiesław KRZEMIŃSKI, Katarzyna KOPEĆ and Robert A. CORAM Worcestobiidae - a new Triassic family of Mecoptera, based on species removed from the family Orthophlebiidae

Wiesław KRZEMIŃSKI, Agnieszka SOSZYŃSKA-MAJ, Katarzyna KOPEĆ and Irena D. SUKATSHEVA

The oldest representative of the family Austropanorpidae (Mecoptera) from the Lower Jurassic of Siberia

Katarzyna KOPEĆ, Wiesław KRZEMIŃSKI, Agnieszka SOSZYŃSKA-MAJ, Yizi CAO and Dong REN

A new species of Orthobittacus (Mecoptera, Bittacidae) from the Middle Jurassic of Daohugou, Inner Mongolia (China) 
Katarzyna KOPEĆ, Agnieszka SOSZYŃSKA-MAJ, Alexander GEHLER, Jörg ANSORGE and Wiesław KRZEMIŃSKI

Mecoptera and Diptera from the early Toarcian (Early Jurassic) deposits of Wolfsburg - Große Kley

(Lower Saxony, Germany)

Ewa KRZEMIŃSKA and Elena LUKASHEVICH

The oldest Trichoceridae (Diptera) from the Lower Jurassic of Kyrgyzstan: implications of the

biomechanical properties of their wings

He WANG, Yan FANG, Qingqing ZHANG, Xiaojie LEI, Bo WANG, Edmund A. JARZEMBOWSKI and Haichun ZHANG

New material of Sigmaboilus (Insecta, Orthoptera, Prophalangopsidae) from the Jurassic Daohugou Beds,

Inner Mongolia, China

Daran ZHENG, Haichun ZHANG, Bo WANG and Su-Chin CHANG

A new species of damsel-dragonfly (Odonata: Stenophlebiidae: Cretastenophlebia) from the Lower

Cretaceous of the Jiuquan Basin, northwestern China

Ed JARZEMBOWSKI and Agnieszka SOSZYŃSKA-MAJ

The first orthophlebiid scorpionfly (Insecta: Mecoptera) from the Wealden (Lower Cretaceous) of southern England

Alexander V. KHRAMOV

A new assemblage of Early Cretaceous green lacewings (Chrysopidae: Neuroptera) from Transbaikalia

Victoria E. McCOY, Carmen SORIANO and Sarah E. GABBOTT

A review of preservational variation of fossil inclusions in amber of different chemical groups

Wilfried WICHARD and Dany AZAR

First caddisflies (Trichoptera) in Lower Cretaceous Lebanese amber

Ryszard SZADZIEWSKI

Biting midges (Diptera: Ceratopogonidae) as indicators of biostratigraphy, ecological reconstructions and identification of amber deposits

Iwona KANIA, Wiesław KRZEMIŃSKI and Antonio ARILLO

A new peculiar species of the genus Helius Lepeletier \& Serville, 1828 (Diptera, Limoniidae) from

Cretaceous Álava amber (Spain)

Ru D. A. SMITH and Andrew J. ROSS

Amberground pholadid bivalve borings and inclusions in Burmese amber: implications for proximity of resin-producing forests to brackish waters, and the age of the amber

Wolfram MEY, Wilfried WICHARD, Emma ROSS and Andrew ROSS

On the systematic position of a highly derived amphiesmenopteran insect from Burmese amber

(Insecta, Amphiesmenoptera)

Marta ZAKRZEWSKA, Frauke STEBNER, Mateusz PUCHALSKI, Hukam SINGH and Wojciech GItKA

A peculiar leg structure in the first non-biting midge described from Cambay amber, India (Diptera:

Chironomidae)

Iwona KANIA, Wiesław KRZEMIŃSKI, Frauke STEBNER and Hukam SINGH

The first representative of Tipulomorpha (Diptera) from Early Eocene Cambay amber (India)

Wiesław KRZEMIŃSKI, Iwona KANIA and Maciej WOJTOŃ

A new Eocene Dicranomyia Stephens, 1829 (Diptera: Limoniidae) from Baltic amber

Alicja Magdalena BRYSZ and Jacek SZWEDO

The fossil record of the planthopper family Achilidae, with particular reference to those in Baltic amber

(Hemiptera: Fulgoromorpha) 
Jiří KOLIBÁČ and Vitalii ALEKSEEV

Seidlitzella hoffeinsorum sp. nov., the first representative of the beetle tribe Gymnochilini (Coleoptera:

Trogossitidae) from Baltic amber

Evgeny PERKOVSKY and Piotr WEGIEREK

Aphid-Buchnera-Ant symbiosis; or why are aphids rare in the tropics and very rare further south?

Elina KETTUNEN, Alexander R. SCHMIDT, Paul DIEDERICH, Heinrich GRABENHORST and Jouko RIKKINEN

Diversity of lichen-associated filamentous fungi preserved in European Paleogene amber

Ulla KAASALAINEN, Jochen HEINRICHS, Matthew A. M. RENNER, Lars HEDENÄS,

Alfons SCHÄFER-VERWIMP, Gaik Ee LEE, Michael S. IGNATOV, Jouko RIKKINEN and

Alexander R. SCHMIDT

A Caribbean epiphyte community preserved in Miocene Dominican amber

$321-331$

Richard A. BATCHELOR

Do Neoproterozoic (Moine) calc-silicate rocks represent metamorphosed tuffs? A geochemical reappraisal

Francis M. ELLIOTT

An early actinopterygian ichthyofauna from the Scottish Lower Coal Measures Formation: Westphalian A (Bashkirian)

CONTENTS OF VOLUME 107

AUTHOR INDEX TO VOLUME 107 


\section{AUTHOR INDEX TO VOLUME 107}

ALEKSEEV, V., 289

ANSORGE, J., 163

ARILLO, A., 231

AZAR, D., 213

BABA, M., 23

BATCHELOR, R. A., 333

BELL, B. R., 53

BOWDEN, S., 23

BRUSATTE, S. L., 1

BRYSZ, A. M., 279

CAO, Y., 157

CHALLANDS, T. J., 1

CHANG, Su-Chin, 185

CLARK, N. D. L., 91

CORAM, R. A., 145

DIEDERICH, P., 311

DU TIEN HAT, E., 79

ELLIOTT, F. M., 351

FANG, Yan, 177

FLOYD, J. D., 13

FOFFA, D., 1

GABBOTT, S. E., 203

GEHLER, A., 163

GIŁKA, W., 255

GRABENHORST, H., 311

GUERIAU, P., 79

HEDENÄS, L., 321

HEINRICHS, J.,

HUDSON, J. D., 1

IGNATOV, M. S., 321

JARZEMBOWSKI, E. A., 99, 129, 177, 191

KAASALAINEN, U., 321

KAKUWA, Y., 13

KANIA, I., 231, 263, 271

KELLY, R. S., 129

KETTUNEN, E., 311

KHRAMOV, A. V., 195

KOLIBÁČ, J., 289

KOPEĆ, K., 145, 151, 157, 163

KRZEMIŃSKA, E., 173

KRZEMIŃSKI, W., 145, 151, 157, 163, 231, 263, 271
LEE, Gaik Ee, 321

LEI, Xiaojie, 177

LUKASHEVICH, E., 173

McCOBB, L. M. E., 33

MCCOY, V. E., 203

MEY, W., 249

MILLER, R. M., 91

PARNELL, J., 23

PECHAROVÁ, M., 99

PERKOVSKY, E., 297

POPOV, L. E., 33

PROKOP, J., 99

PUCHALSKI, M., 255

RABET, N., 79

REN, D., 157

RENNER, M. A. M., 321

RIKKINEN, J., 311, 321

ROSS, A. J., 73, 91, 99, 129, 239, 249

ROSS, D. A., 1

ROSS, E., 249

SCHÄFER-VERWIMP, 321

SCHMIDT, A. R., 311, 321

SINGH, H., 255, 263

SMITH, R. D. A., 239

SORIANO, C., 203

SOSZYŃSKA-MAJ, A., 145, 151, 157, 163, 191

STEBNER, F., 255, 263

SUKATSHEVA, I. D., 151

SZADZIEWSKI, R., 219

SZWEDO, J., 109, 279

TENNANT, J. P., 1

WANG, Bo, 177, 185

WANG, He, 177

WEGIEREK, P., 297

WICHARD, W., 213, 249

WILLIAMSON, I. T., 53

WOJTOŃ, M., 271

YI, Hongyu, 1

YOUNG, M. T., 1

ZAKRZEWSKA, M., 255

ZHANG, Haichun, 177, 185

ZHANG, Qingqing, 177

ZHENG, Daran, 185 